\title{
IMPLIKASI PEMBELAJARAAN JARAK JAUH TERHADAP KETERCAPAIAN KOMPETENSI PENDIDIKAN AGAMA ISLAM DAN BUDI PEKERTI DI SD PLUS AR-RAHMAT BANDUNG
}

\author{
Delis Sri Maryati
}

Email: delis.sri.maryati@gmail.com

\begin{abstract}
The purpose of this study was to determine the implications of distance learning carried out related to the achievement of student competencies, including Attitude Competencies, namely Spiritual and Social, Knowledge, and Skills. The training was carried out to overcome the problems faced, namely training on the use of LMS and PJJ applications, training on distance learning methods, and training in making ICT-based teaching materials. Effective communication with parents is needed to achieve competency achievement.
\end{abstract}

Keywords : Learning Implications, Competence Achievement, Budi Pekerti

\begin{abstract}
Abstrak
Tujuan penelitian ini untuk mengetahui Implikasi dari pembelajaran jarak jauh yang dilakukan berhubungan dengan ketercapaian kompetensi peserta didik, meliputi Kompetensi Sikap, yakni Spiritual dan Sosial, Pengetahuan, dan Ketrampilan. Pelatihan dilakukan untuk mengatasi permasalahan yang dihadapi, yaitu Pelatihan penggunaan LMS dan Aplikasi PJJ, Pelatihan metode pembelajaran jarak jauh, dan pelatihan pembuatan bahan ajar berbasis TIK. Komunikasi efektif dengan orang tua diperlukan guna mencapai ketercapaian kompetensi.
\end{abstract}

Kata Kunci : Implikasi Pembelajaraan, Ketercapaian Kompetensi, Budi Pekerti 


\section{Pendahuluan}

Manajemen merupakan proses untuk mencapai tujuan organisasi oleh seseorang atau sekelompok orang melalui penggunaan berbagai fungsi yakni perencanaan, pengorganisasian, kepemimpinan, serta pengendalian. Pembelajaran merupakan kegiatan dimana terjadi interaksi antar peserta didik, peserta didik dengan lingkungan belajarnya dengan tujuan perubahan tingkah laku konstruktif yang dimiliki peserta didik.

Berdasarkan hal tersebut maka manajemen pembelajaran diartikan sebagai aktivitas kegiatan belajar dan mengajar melalui penerapan prinsip pembelajaran dengan langkah-langkah pembelajaran meliputi perencanaan, pelaksanaan, serta evaluasi agar rencana serta tujuan yang ditetapkan dapat tercapai (Muhlasin, 2019).

Dalam Pendidikan Agama Islam (PAI) dan Budi Pekerti (BP) Manajemen pembelajaran ialah proses integrasi kegiatan belajar mengajar oleh guru yang dimulai perencanaan kegiatan belajar mengajar, evaluasi, serta tindak lanjut melalui kegiatan mendidik guna tercapainya tujuan yang terdapat dalam nilai agama Islam (Nurseha, 2018).
Pembelajaran jarak jauh adalah alternatif yang terpaksa dilakukan dalam masa pandemi Covid-19 yang dimulai di bulan Maret 2020. Pembelajaran jarak jauh atau disebut dengan pembelajaran dalam lingkaran (daring), on-line, dan e-learning. Gross, Muskarella, dan Pirkl mendefinisikan pembelajaran jarak jauh adalah suatu pembelajaran yang melakukan perluasan ataupun pemberian instruksi tidak dalam ruang kelas tetapi melalui lokasi lain dengan teknologi komputer, audio, video, alat komunikasi, multimedia, maupun kombinsai dari berbagai teknologi (Sanjaya (Editor), 2020).

Pembelajaran daring adalah suatu kegiatan pembelajaran tanpa bertatap muka secara langsung, namun digantikan dengan pemakaian platform untuk membantu dalam proses kegiatan pembelajaran walaupun dari jarak yang jauh. Tujuan pembelajaran daring yaitu untuk memperbaiki mutu kegiatan dan layanan melalui jaringan internet dan terbuka untuk mencapai minat serta ruangruang belajar. (Handarini \& Wulandari, 2020). Pendidikan jarak jauh sendiri sebenarnya telah dikenal selama bertahuntahun lalu, dimana pengertian dan batasan mengenai pendidikan jarak jauh ini terus 
meberkembang dari waktu ke waktu. Hal ini membuat para ahli terus mengadakan penelitian dan analisis yang ahirnya menyimpulkan batasan atau karakteristik tertentu. Keegan mengatakan batasan atau karakteristik pendidikan jarak jauh menjadi tiga pokok (Syukur, 2005). Pertama, peserta didik dan guru beraktivitas terpisah dalam kegiatan belajar. Kedua, Pelajaran disampaikan kepada siswa melalui media. Ketiga, komunikasi yang terjadi diusahakan terjadi melalui dua arah, peserta didik dan guru, peserta didik dan lembaga penyelengara, serta antara sesama peserta didik.

Penyelenggaraan Pendidikan Agama Islam dan Budi Pekerti pada sekolah harus mengintegrasikan berbagai aspek pengajaran, yakni pengamalan serta pengalaman peserta didik. Hal ini berarti kegiatan dalam proses belajar mengajar dalam kelas wajib diimbangi dengan kegiatan pembiasaan melaksanakan ibadah di sekolah, mempunyai keterkaitan dan hubungan baik dengan lingkungan sekitar sekolah, serta penerapan nilai dan norma akhlak terpuji. Problematika Pendidikan Agama Islam dan Budi Pekerti sekarang ini adalah pelaksanaan pembelajaran karena diakibatkan pandemi Covid-19. Proses pembelajaran pada Pendidikan
Agama Islam dan Budi Pekerti di masa pandemi Covid-19 ini seakan mengalami lompatan ke belakang. Problematika ini dapat dilihat dari sisi kesiapan lembaga pendidikan dalam sarana dan prasarana, serta guru dan peserta didik dalam proses kegiatan pembelajaran. Proses belajar dan mengajar tidak bisa dilaksanakan secara optimal, terutama dalam hal penguasaan kompetensi ketrampilan dan pembiasan beribadah serta akhlaqul karimah.

Berkaitan dengan pandemi virus Covid-19 Kemendikbud RI mengambil kebijakan dengan dikeluarkannya surat edaran bernomor 4 tahun 2020 mengenai Pelaksanaan Kebijakan Pendidikan dalam Masa Darurat Penyebaran Corona Virus Disease (Covid-19) dan SE nomor 15 tahun 2020 mengenai Pedoman Penyelenggaran Belajar dari Rumah dalam Masa Darurat Penyebaran Corona Virus Disease (Covid-19). Pembelajaran jarak jauh adalah langkah yang paling logis untuk dipilih. Dinamika dan Problematika terjadi mewarnai pendidikan jarak jauh yang dilakukan, demikian juga pada Pendidikan Agama Islam dan Budi Pekerti. Ketidaksiapan menghadapi kondisi di luar prediksi ini membuat praktisi pendidikan harus memikirkan solusi yang tepat agar pendidikan tetap 
berlangsung meskipun dalam keterbatasan, terutama keterbatasan dalam kegiatan pembelajaran jarak jauh.

\section{Metode Penelitian}

Penelitian ini adalah penelitian kualitatif deskriptif. Sedangkan teknik pengumpulan data menggunakan observasi, angket, wawancara, dan studi dokumen. Data yang telah terkumpul dianalisis dengan menelaah seluruh datadata yang diperoleh, disusun dibandingkan untuk ditarik kesimpulan demi memperoleh jawaban dari permasalahan.

\section{Hasil dan Pembahasan}

Penggunan metode pembelajaran jarak jauh yang digunakan berimplikasi pada ketercapaian kompetensi peserta didik. Peserta didik harus menguasai kompetensi yang termaktub dalam kompetisi inti. Kompetensi tersebut meliputi kompetensi sikap, kompetensi pengetahuan, dan kompetensi ketrampilan. Kompetensi inti adalah standar kualitas lulusan sesudah menamatkan pendidikan pada suatu satuan pendidikan. Kompetensi inti ini menggambarkan hasil dari suatu proses pembelajaran yangdilakukan. Kompetensi inti adalah kompetensi utama yang digolongkan pada aspek sikap, aspek pengetahuan, juga aspek ketrampilan yang harus dikuasai pada setiap tingkatan baik tingkatan sekolah, tingkatan kelas, maupun mata pelajaran (Mulyasa, 2013).

Kompetensi inti mengidentifikasikan mutu yang berimbang antara kemampuan dalam penguasaan pengetahuan dan kemampuan penguasaan berbagai ketrampilan yang dicapai. Untuk mempermudah pencapaian tujuan, pada kompetensi inti, terjadi pembagian pada ranah sikap. Kompetensi pada ranah sikap diperinci menjadi dua, yakni aspek spiritual dan aspek sosial. Sikap spiritual berkaitan dengan tujuan dalam pendidikan nasional untuk mendidik peserta didik menjadi insan yang beriman dan bertakwa. Sikap sosial terkait dengan tujuan pendidikan nasional dalam pembentukan peserta didik yang mempunyai akhlak mulia, demokratis, mandiri, serta bertanggung jawab. Sehingga rumusan KI menjadi KI-1 sikap spiritual, KI-2 sikap sosial KI-3 Pengetahuan KI-4 Ketrampilan. Kompetensi sikap spiritual adalah usaha dalam membentuk anak didik menjadi insan dengan keimanan dan kertaqwaan kepada Tuhan YME melalui penghormatan, penghayatan, dan pengamalan ajaran agama yang dianut (Kurniasih, 2014). 
Kompetensi sikap sosial adalah sikap yang dimiliki seseorang berkaitan dengan dirinya dan orang lain atau masyarakat yang mempunyai tujuan menjaga hubungan baik dengan orang lain, agar bisa hidup berdampingan dan saling memberikan manfaat (Wiguna, 2017).

Pada pencapaian kompetensi spiritual dan sosial yang biasanya dilakukan denga teknik observasi, penilaiai diri sendiri, dan penilaian teman sebaya tidak bisa maksimal dilaksankan. Terutama observasi secara langsung sikap spiritual dan sosial peserta didik. Penilaian teman sebaya pun demikian. Kompetensi pengetahuan mencerminkan konsepkonsep keilmuan yang seharusnya dikuasai oleh peserta didik setelah melewati rangkaian kegiatan proses belajar mengajar. Terdapat 4 dimensi pengetahuan yaitu pengetahuan faktual, konseptual, prosedural, serta metakognitif yang meliputi ketrampilan dalam berpikir mulai dari tingkatan bawah atau rendah hingga tingkat tertinggi (Khotimah, 2019).

Sebagian besar responden menyatakan metode pembelajaran yang dipilih dan dan digunakan sangat mendukung ketercapaian kompetensi pengetahuan. Pada kompetensi pengetahuan proses penilaian dapat dilaksankan dengan baik secara daring. Responden yang menyatakan kurang tercapai pada kompetensi pengetahuan dikarenakan permasalahan hanya pada tingkat partisipasi peserta didik yang tidak maksimal. Kurangnya motivasi siswa dalam PJJ menjadi problematika yang penting untuk selalu diperhatikan. Imbas dari rendahnya motivasi siswa dalam tingkat partisispasi rendah dalam mengikuti PJJ, keengganan mengerjakan tugas, dan penguasaan materi pembelajaran. Untuk meningkatkan motivasi dan partisipasi siswa maka kegiatan-kegiatan daring yang menarik dapat dilakukan.

Ragamnya program dari internet, kemudahan akses internet, serta berbagai fitur teknologi seperti aplikasi games online menjadi pisau bermata dua. Sangat menguntungkan, namun disisi lain menimbulkan ketertarikan peserta didik untuk menjelajahi sehingga mengalihkan dari fungsi utamanya. Dimana perhatian peserta didik terhadap PJJ berkurang karena keasyikan bereksplorasi, sehingga kuota lebih sering digunkaan untuk kegiatan browshing, games, dan bermain medsos.

Proses penilaian agar mencapai input yang maksimal harus dilakukan dengan 
kombinasi berbagai LMS dan aplikasi daring maupun luring dalam pengambilan dan penyerahan tugas mandiri. Flexibilitas dalam proses penilaian dan waktu pengumpulan tugas menjadi langkah yang harus digunakan demi ketercapaian kompetensi pengetahuan peserta didik. kegiatan-kegiatan daring yang menarik dilakukan untuk meningkatakan motivasi dan partisipasiswa. Kompetensi keterampilan yang diharapkan dalam kurikulum 2013 yaitu keterampilan yang berguna untuk mengembangkan dan mengeksplorasi pengetahuan (Khotimah, 2019).

Kompetensi keterampilan juga setara dengan kompetensi pengetahuan alasannya adalah supaya peserta didik tidak hanya mengetahui teori namun yang lebih penting adalah mengetahui aplikasi dan dapat merealisasikannya.

Pada kompetensi ketrampilan responden menemui permasalahan, terutama pada materi penguasan ketrampilan praktek beribadah, karena guru tidak dapat secara langsung memantau. Sehingga kesulitannya adalah peserta didik tidak mendapatkan bimbingan secara maksimal. PJJ membutuhkan partisispasi orang tua yang tinggi, karena kegiatan PJJ dilakukan di rumah.

Fungsi guru sebagai pembimbing dan pengawas pembelajaran beralih kepada orang tua. Hal ini tidak dapat secara maksimal dilaksanakan karena tingkat pendidikan yang beragam, faktor kesibukan, faktor sosial ekonomi, dan faktor emosional orang tua peserta didik. Pembuatan jaringan komunikasi yang efektif antara fihak sekolah, guru dengan wali maupun orang tua dari peserta didik dan kegiatan home visit bisa menjadi solusi permasalahn ini.

Permasalahan pokok dalam PJJ adalah kepemilikan alat yang mendukung pembelajaran seperti HP, komputer atau laptop, dan ketersediaan kuota maupun signal dari operator selular. Hal ini dapat dilihat dengan masih dapat ditemukan peserta didik yang tidak mempunyai HP, penggunaan HP secara bergantian dalam keluarga, dan kualifikasi HP yang digunakan. Problem signal dan kuota merupakan hal yang paling banyak dikeluhkan oleh peserta didik. Penyediaan sarana prasarana di sekolah yang bisa diakses oleh peserta didik yang mengalami kendala dapat menjadi solusi. Dengan menerapkan protokol kesehatan peserta didik yang memiliki keterbatasan sarana 
dan prasarana PJJ di rumah dapat menggunakan fasilitas sekolah. Program pemberian kuota belajar dari kemendikbud membantu dalam masalah kuota serta mengurangi keluhan baik dari orangtua maupun peserta didik.

\section{Kesimpulan}

Implikasi penggunaan metode pembelajaran terhadap kompetensi yang dicapai peserta didik mendukung ketercapaian kompetensi pengetahuan, tetapi disisi lain terutama pada kompetensi spiritual, sikap, serta ketrampilan memerlukan peran orang tua yang besar dalam ketercapaian kompetensi peserta didik.

\section{A. Daftar Pustaka}

Irawan, dkk (2020). Pendidikan Tinggi Di Masa Pandemi : Transformasi, Adaptasi, dan Metamorfosis Menyongsong New Normal. Zahir Publishing.

Kadri, M., \& Rahmawati, M. (2015). Pengaruh model pembelajaran discovery learning terhadap hasil belajar siswa pada materi pokok suhu dan kalor. Jurnal Ikatan Alumni Fisika Universitas Negeri Medan, 1(1), 21-24.

Kemendikbud. (2014). Pendekatan dan strategi scientific. Kemendikbud.

Kementerian Agama. (2014). Panduan Pendekatan Saintifik Kurikulum
2013 Pendidikan Agama dan Budi Pekerti.

Muhlasin, M. (2019). Manajemen Pembelajaran dalam Rangka Meningkatkan Prestasi Belajar. Akademika, 15(1), 62-75.

Mulyasa, E. (2013). Pengembangan dan implementasi kurikulum 2013 (Cetakan pertama). PT Remaja Rosdakarya.

Mu'ayyadah, and Noor Fatmawati. 2021. "Pemanfaatan Teknologi Sebagai Pembelajaran E-Learning Google Classroom Pada Mata Pelajaran IPS." Asanka : Journal of Social Science and Education2 (1):31-45. https://jurnal.iainponorogo.ac.id/in dex.php/asanka/article/view/2364.

Nugroho, T. (2014). Pendekatan scientific, model, dan strategi pembelajaran dalam kurikulum 2013. Lingua Humaniora, 8, 797-808.

Nurseha, A. (2018). Manajemen Pembelajaran Pendidikan Agama Islam di Sekolah. AN NIDA JOURNAL, 7(1), Article 1. http://103.66.199.204/index.php/ NIDA/article/view/340

Wardhana, A. C., Segara, A. J. T., Adhinata, F. D., \& Rakhmadani, D. P. (2020). Pelatihan Pembelajaran Jarak Jauh Menggunakan Learning Management System Berbasis Moodle Untuk Guru Di SMK Maarif NU 2 Ajibarang. LOGISTA - Jurnal Ilmiah Pengabdian Kepada Masyarakat, 
4(2),

$231-237$.

https://doi.org/10.25077/logista.4.

2.231-237.202 